\title{
Analisis kemampuan pemecahan masalah siswa dalam menyelesaikan soal cerita barisan ditinjau dari adversity quotient
}

\author{
Linda Nur Chabibah ${ }^{{ }^{*}}$, Emy Siswanah ${ }^{2}$, Dyan Falasifa Tsani ${ }^{1}$ \\ ${ }^{1}$ Program Studi Pendidikan Matematika, Universitas Islam Negeri Walisongo Semarang, Indonesia \\ 2 Program Studi Matematika, Universitas Islam Negeri Walisongo Semarang, Indonesia \\ * Corresponding Author. E-mail: linda.nurchabibah@gmail.com
}

\begin{tabular}{|c|c|}
\hline ARTICLE INFO & ABSTRACT \\
\hline $\begin{array}{l}\text { Article History: } \\
\text { Received: } 23 \text { Dec. } 2019 \\
\text { Revised: } 26 \text { Dec. } 2019 \\
\text { Accepted: } 28 \text { Dec. } 2019 \\
\text { Keywords: } \\
\text { Kemampuan pemecahan } \\
\text { masalah, } \\
\text { Soal cerita, } \\
\text { Adversity quotient, } \\
\text { Problem-solving ability, } \\
\text { Word problem. }\end{array}$ & $\begin{array}{l}\text { Tujuan dari penelitian kualitatif ini adalah untuk mendeskripsikan kemampuan pemecahan } \\
\text { masalah siswa dalam menyelesaikan soal cerita pada materi barisan ditinjau dari Adversity } \\
\text { Quotient (AQ). Kemampuan pemecahan masalah memiliki } 4 \text { indikator yaitu: 1) mengiden- } \\
\text { tifikasi masalah, 2) merumuskan masalah, 3) melaksanakan strategi, dan 4) memverifikasi } \\
\text { solusi. Penelitian dilaksanakan pada semester genap tahun ajaran 2018/2019. Subjek pene- } \\
\text { litian terdiri dari } 30 \text { Siswa kelas XI IPA } 1 \text { SMA Kesatrian } 1 \text { Semarang yang telah diajarkan materi } \\
\text { barisan. Kemudian dipilih subjek berdasarkan tipe AQ yaitu Climber, Camper dan Quitter. } \\
\text { Teknik pengumpulan data menggunakan angket AQ, tes kemampuan pemecahan masalah, } \\
\text { dan wawancara. Teknik analisis data penelitian ini meliputi reduksi data, penyajian data, dan } \\
\text { penarikan kesimpulan/verifikasi. Hasil penelitian menunjukkan bahwa siswa bertipe Climber } \\
\text { mampu memenuhi seluruh indikator dari } 4 \text { indikator kemampuan pemecahan masalah yaitu } \\
\text { indikator } 1,2,3 \text {, dan } 4 \text {. Siswa bertipe Camper mampu memenuhi } 3 \text { dari } 4 \text { indikator kemam- } \\
\text { puan pemecahan masalah yaitu indikator } 1,2 \text {, dan } 3 \text {. Siswa bertipe Quitter hanya mampu } \\
\text { memenuhi } 1 \text { indikator kemampuan pemecahan masalah yaitu indikator } 2 \text {. }\end{array}$ \\
\hline
\end{tabular}

The purpose of this qualitative research was to describe the students' problem-solving abilities in solving word problems in the sequences material in terms of Adversity Quotient (AQ). Problem-solving has four indicators namely: 1) overcoming the problem, 2) formulating the problem, 3) implementing the strategy, and 4) verifying the solution. The study was conducted in the even semester of the 2018/2019 academic year. The research subjects consisted of 30 students of class XI IPA 1 of Kesatrian 1 Semarang High School who had taught the sequences material. Then the subject was chosen based on the type of $A Q$ namely climber, camper and quitter. Data collection techniques using the AQ questionnaire, the problem-solving test, and interview. The data analysis techniques of this study include data reduction, data presentation, and conclusion. The results showed that students of the climber type were able to meet all the indicators of the four indicators of problem-solving namely indicators 1, 2, 3, and 4. Students of the camper type were able to fulfill three from four indicators of problem-solving namely indicators 1, 2, and 3. Students' quitter type were only able to meet one indicator of problemsolving, namely indicator 2.

\section{SCAN ME}

This is an open access article under the CC-BY-SA license

\section{How to Cite:}

Chabibah, L. N., Siswanah, E., \& Tsani, D. F. (2019). Analisis kemampuan pemecahan masalah siswa dalam menyelesaikan soal cerita barisan ditinjau dari adversity quotient. PYTHAGORAS: Jurnal Pendidikan Matematika, 14(2), 199-210. doi: https://doi.org/10.21831/pg.v14i2.29024

https://doi.org/10.21831/pg.v14i2.29024

\section{PENDAHULUAN}

The National Council of Teachers of Mathematics (2000, p.4) menjelaskan bahwa standar proses dalam pembelajaran matematika meliputi problem-solving, reasoning and proof, communication, connection, dan representation. Hal ini menjelaskan betapa pentingnya pemecahan masalah (problem-solving) bagi siswa dalam 
pembelajaran matematika. Selain itu, pemecahan masalah menjadi standar internasional yang harus dilampaui siswa untuk menghadapi tantangan-tantangan bagi generasi sekarang.

Kemampuan pemecahan masalah juga menjadi tujuan pembelajaran matematika. Pembelajaran matematika bertujuan agar siswa: (1) memahami konsep matematika, (2) menggunakan penalaran pada materi yang memuat pola dan sifat, (3) memecahkan masalah, (4) mengkomunikasikan gagasan siswa dengan simbol, diagram atau tabel untuk memperjelas permasalahan, (5) siswa mempunyai sikap menghargai manfaat matematika dalam kehidupan (Depdiknas, 2006). Sekarang ini tujuan pembelajaran matematika yaitu agar siswa menunjukkan sikap positif bermatematika yang meliputi logis, kritis, cermat dan teliti, jujur, bertanggung jawab, dan tidak mudah menyerah dalam menyelesaikan masalah, sebagai wujud implementasi kebiasaan dalam inkuiri dan eksplorasi matematika (Kemendikbud, 2016). Berdasarkan uraian tersebut, tampak jelas bahwa kemampuan pemecahan masalah sangat penting dan menjadi suatu keharusan, terutama untuk menghadapi era globalisasi serta era perdagangan bebas, kemampuan pemecahan masalah menjadi hal yang sangat menentukan untuk suatu keberhasilan dalam menghadapi era ini.

Pemecahan masalah juga sangat berguna bagi siswa dalam mendalami materi matematika lainnya (Amri \& Abadi, 2013; Rianto \& Santoso, 2014). Pemecahan masalah juga berguna dalam memecahkan masalah sehari-hari, karena dalam aktivitas sehari-hari manusia tidak luput dari proses matematika (Arfiana \& Wijaya, 2018; Marlissa \& Widjajanti, 2015). Beberapa ahli mengemukakan pendapat terkait pemecahan masalah. Polya (1957) mengemukakan bahwa langkah-langkah pemecahan masalah meliputi memahami masalah, merencanakan strategi pemecahan masalah, menerapkan rencana pemecahan masalah, dan meninjau kembali. Bransford dan Stein (1993) mengemukakan langkah-langkah pemecahan masalah meliputi mengidentifikasi masalah, menentukan tujuan, mengeksplorasi strategi yang mungkin, menerapkan strategi, dan meninjau kembali solusi yang ditemukan. Dari kedua pendapat tersebut dapat disimpulkan bahwa pemecahan masalah memiliki 4 indikator yaitu: (1) mengidentifikasi masalah, (2) merumuskan strategi, (3) melaksanakan strategi, dan (4) memverifikasi solusi.

Salah satu bentuk permasalahan yang dapat digunakan dalam aktivitas pemecahan masalah adalah soal cerita (word problem) (Kong \& Orosco, 2016; Sajadi, Amiripour, Rostamy-Malkhalifeh, 2013). Dengan soal cerita, memungkinkan bagi siswa untuk mentransfer pengetahuan matematika formal dan keterampilan yang siswa pelajari di sekolah ke dalam kehidupan sehari-hari (Greer, 1997; Verschaffel, De Corte, \& Vierstraete, 1999). Dengan demikian, soal cerita dapat digunakan untuk menganalisis lebih rinci kemampuan tiap siswa. Soal cerita biasanya diambil dari masalah di lingkungan siswa, sehingga siswa akan merasa antusias dalam menyelesaikan masalah tersebut (Depaepe, De Corte, \& Verschaffel, 2010; Verschaffel, Greer, \& De Corte, 2000).

Saat memecahkan suatu masalah, siswa pasti akan dihadapkan dengan berbagai hambatan, kesulitan dan tantangan saat menyelesaikan suatu permasalahan (Hadi, Retnawati, Munadi, Apino, \& Wulandari, 2018). Telah diketahui bahwa karakter setiap siswa tidaklah sama, begitu juga dengan latar belakang masing-masing siswa sendiri. Kesuksesan dalam memecahkan suatu masalah pasti dipengaruhi oleh beberapa faktor, sehingga mampu dalam menjawab soal pemecahan masalah. Faktor yang sering dibicarakan dan diteliti biasanya seputar Intelegence Quotient (IQ), Emotional Quotient (EQ) dan Spiritual Quotient (SQ). Akan tetapi ada lagi faktor penentu dalam kesuksesan yang mungkin masih asing di telinga kita yaitu Adversity Quotient (AQ).

Beberapa hasil penelitian melaporkan bahwa terdapat hubungan positif antara AQ dengan pemecahan masalah (misalnya Espaňola, 2016; Khairani \& Abdullah, 2018; Mustika, Yurniwati dan Lukman, 2018), sehingga semakin tinggi nilai $\mathrm{AQ}$ siswa maka semakin tinggi pula kemampuan pemecahan masalahnya. Parvathy dan Praseeda (2014) juga melaporkan bahwa semakin rendah AQ seseorang maka masalah-masalah akademik yang dihadapi siswa akan cenderung meningkat. Hal ini jelas menunjukkan bahwa AQ berperan penting bagi kesuksesan belajar siswa.

AQ pertama kali dikembangkan oleh Paul G. Stoltz. Stoltz (2000, p.16) mengungkapkan bahwa IQ (Intelligence Quotient) dan EQ (Emotional Quotient) tidaklah cukup dalam menunjang kesuksesan, diperlukan daya juang, motivasi dan sikap pantang menyerah dalam menggapai kesuksesan atau biasa disebut AQ. AQ juga sebagai suatu ukuran untuk mengetahui respon seseorang terhadap kesulitan dan tantangan yang dihadapinya. Berdasarkan $A Q$, seseorang dapat digolongkan kedalam Quitter, Camper, dan Climber (Stoltz, 2000). Quitter adalah tipe seseorang yang putus asa dalam menjalani suatu permasalahan. Camper adalah tipe seseorang yang hanya nyaman dengan keadaan yang sedang ia hadapi, sangat jarang untuk mengambil risiko dalam menghadapi suatu permasalahan. Sedangkan Climber adalah tipe seseorang yang selalu menginginkan yang terbaik dalam segalanya, serta berani menghadapi tantangan. 
Berdasarkan uraian yang dikemukakan sebelumnya, diketahui bahwa AQ setiap siswa berbeda-beda dalam proses belajar dan dapat mempengaruhi kemampuan siswa dalam pemecahan masalah. Informasi terkait bagaimana proses pemecahan masalah yang dilakukan siswa ditinjau dari tipe $A Q$ yang dimilikinya dapat dimanfaatkan untuk perbaikan proses pembelajaran matematika. Dengan demikian, penelitian bertujuan untuk mendeskripsikan kemampuan pemecahan masalah siswa dalam menyelesaikan soal cerita barisan ditinjau dari Adversity Quotient.

\section{METODE}

Penelitian deskriptif kualitatif ini dilaksanakan di SMA Kesatrian 1 Semarang, beralamatkan di Jl. Pamularsih Raya No. 116, Gisikdrono, Kota Semarang, Jawa Tengah. Penelitian berlangsung dari tanggal 11 Oktober 2018 hingga 18 Juni 2019. Subjek penelitian ini adalah siswa kelas XI IPA 1 yang berjumlah 30 siswa. Teknik pengumpulan data yang digunakan adalah angket $A Q$, tes kemampuan pemecahan masalah, dan wawancara. Angket $A Q$ digunakan untuk mengelompokkan siswa ke dalam tipe AQ (Quitter, Camper, Climber), tes kemampuan pemecahan masalah dan wawancara digunakan untuk mendapatkan informasi tentang kemampuan pemecahan masalah siswa. Kemudian, teknik analisis data yang digunakan mengacu pada analisis data model Miles dan Huberman. Tahapan dalam menganalisis data kualitatif meliputi reduksi data, penyajian data, dan penarikan kesimpulan/ verifikasi (Miles \& Huberman, 1994). Uji keabsahan data dalam penelitian kualitatif ini meliputi Credibility, transferability, dependability dan confirmability (Sugiyono, 2016, pp.270-277). Adapun uji kredibilitas (validitas internal) menggunakan triangulasi teknik.

Subjek dalam penelitian ini diambil berdasarkan masing-masing tipe AQ yaitu Climber, Camper dan Quitter. Pemilihan subjek menggunakan teknik purposive sampling, didasarkan pada jawaban tes kemampuan pemecahan masalah pada soal cerita barisan. Deskripsi kemampuan pemecahan masalah siswa dideskripsikan berdasarkan pedoman yang dikembangkan peneliti seperti pada Tabel 1.

Tabel 1. Pedoman Penilaian Kemampuan Pemecahan Masalah

\begin{tabular}{|c|c|c|}
\hline $\begin{array}{l}\text { Indikator Kemampuan } \\
\text { Pemecahan Masalah }\end{array}$ & Kategori & Deskripsi \\
\hline \multirow[t]{3}{*}{ Mengidentifikasi Masalah } & Mampu & $\begin{array}{l}\text { Mengidentifikasi seluruh unsur yang diketahui dan } \\
\text { ditanyakan secara lengkap dan tepat }\end{array}$ \\
\hline & Kurang Mampu & $\begin{array}{l}\text { Mengidentifikasi unsur yang diketahui dan ditanyakan } \\
\text { kurang lengkap atau kurang tepat }\end{array}$ \\
\hline & Tidak Mampu & $\begin{array}{l}\text { Tidak mengidentifikasi unsur yang diketahui dan } \\
\text { ditanyakan }\end{array}$ \\
\hline \multirow[t]{3}{*}{ Merumuskan strategi } & Mampu & $\begin{array}{l}\text { Rumusan strategi sesuai dengan masalah dan ditulis secara } \\
\text { tepat }\end{array}$ \\
\hline & Kurang Mampu & $\begin{array}{l}\text { Rumusan strategi tidak sesuai dengan pemecahan } \\
\text { masalah }\end{array}$ \\
\hline & Tidak Mampu & Tidak menuliskan rumusan masalah \\
\hline \multirow[t]{3}{*}{ Melaksanakan Strategi } & Mampu & $\begin{array}{l}\text { Melaksanakan seluruh rangkaian perhitungan dengan } \\
\text { tepat }\end{array}$ \\
\hline & Kurang Mampu & $\begin{array}{l}\text { Melaksanakan rangkaian perhitungan dengan kurang } \\
\text { lengkap atau kurang tepat }\end{array}$ \\
\hline & Tidak Mampu & Tidak melaksanakan perhitungan \\
\hline \multirow[t]{3}{*}{ Memverifikasi Solusi } & Mampu & Memverifikasi solusi yang diperoleh dengan tepat \\
\hline & Kurang Mampu & $\begin{array}{l}\text { Memverifikasi solusi tidak sesuai dengan jawaban semula } \\
\text { atau tidak sesuai prosedur dan kurang tepat }\end{array}$ \\
\hline & Tidak Mampu & Tidak memverifikasi solusi yang diperoleh \\
\hline
\end{tabular}

Pedoman penilaian kemampuan pemecahan masalah dijadikan acuan untuk mendeskripsikan kemampuan pemecahan masalah siswa dalam menyelesaikan tes kemampuan pemecahan masalah pada soal cerita barisan. Deskripsi dari hasil kemampuan pemecahan masalah siswa dievaluasi untuk melihat sejauh mana kemampuan pemecahan masalah siswa pada masing-masing tipe $A Q$. 


\section{HASIL DAN PEMBAHASAN}

\section{Hasil Penelitian}

Hasil angket $\mathrm{AQ}$ mengungkapkan bahwa dari keseluruhan jumlah siswa subjek penelitian yang berjumlah 30 siswa, 6 di antaranya bertipe Climber, 20 siswa bertipe Camper, dan 4 siswa bertipe Quitter. Adapun persentase jumlah siswa pada masing-masing tipe AQ dapat dilihat pada Gambar 1.

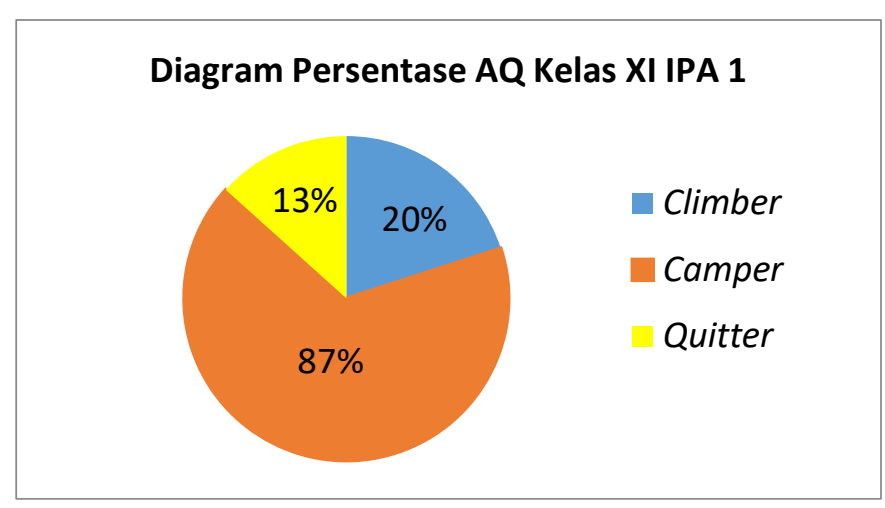

Gambar 1. Diagram Persentase Siswa Berdasarkan Tipe AQ

Subjek penelitian yang sudah dikelompokkan ke dalam masing-masing tipe $A Q$, kemudian menyelesaikan tes kemampuan pemecahan masalah pada soal cerita barisan yang telah divalidasi, diestimasi reliabilitasnya, serta dianalisis tingkat kesukaran dan daya pembedanya. Setelah itu jawaban subjek penelitian dianalisis untuk dijadikan subjek informan. Subjek informan diambil dengan pertimbangan bahwa mereka mempunyai pola jawaban yang hampir sama, karena saat mereduksi data berarti data dirangkum, dipilih hal-hal yang pokok, kemudian dicari tema dan polanya (Sugiyono, 2016, p.244). Pemilihan subjek informan menggunakan teknik purposive sampling.

Setelah subjek dipilih, kemudian peneliti menganalisis kemampuan pemecahan masalah siswa pada materi barisan ditinjau dari AQ. Berikut deskripsi kemampuan pemecahan masalah siswa pada materi barisan ditinjau dari AQ pada soal nomor 1 (Pertumbuhan penduduk suatu kota setiap tahun diasumsikan mengikuti barisan geometri. Pada tahun 2011 pertambahannya sebanyak 4 orang dan pada tahun 2013 sebanyak 64 orang. Pertambahan penduduk pada tahun 2015 adalah...).

Kemampuan Pemecahan Masalah Siswa Tipe Climber

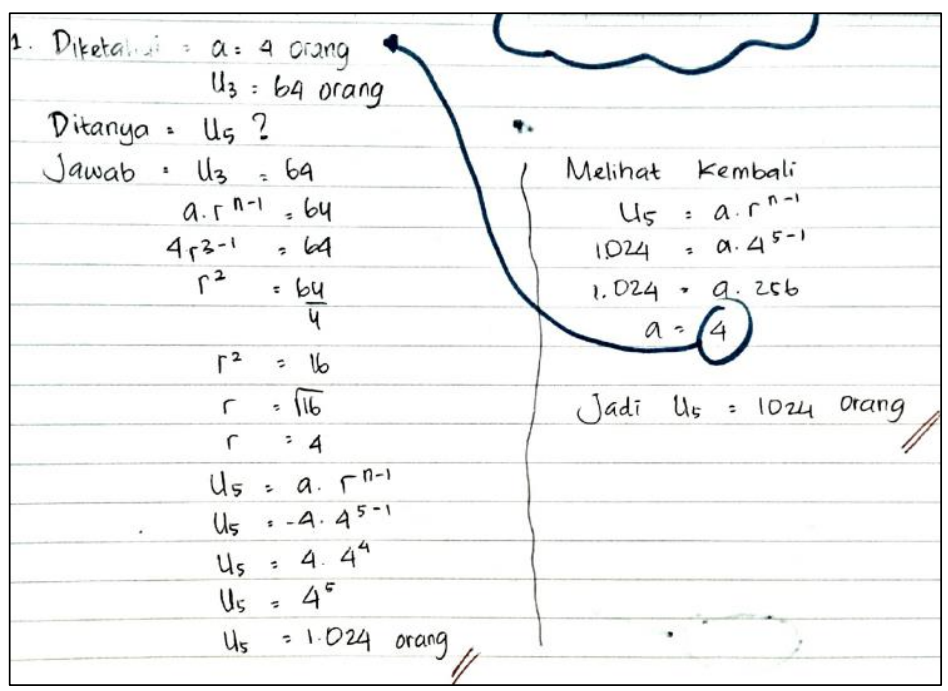

Gambar 2. Jawaban Subjek Informan Climber

Gambar 2 menunjukkan bahwa subjek mampu menuliskan unsur yang diketahui dengan benar dan lengkap, yaitu subjek menyebutkan $a=4$ dan $U_{3}=64$, serta mampu menuliskan unsur yang ditanyakan yaitu $U_{5}$. Akan tetapi rumus yang dipakai oleh subjek informan Climber menggunakan rumus barisan geometri. Penyelesaiannya juga benar dan tepat, subjek menggunakan rumus $U_{n}=a \cdot r^{n-1}$. Tidak lupa subjek mampu memeriksa kembali 
jawaban dengan cara menggunakan hasil yang ditanyakan yaitu hasil $U_{5}$, kemudian kembali menggunakan rumus yang sama yaitu $U_{n}=a \cdot r^{n-1}$ untuk mencari $a$. Sehingga didapatkan nilai $a$ sama seperti yang diketahui. Berdasarkan hasil tes tertulis, subjek informan mampu mengidentifikasi masalah, merumuskan masalah, melaksanakan strategi dan memverifikasi solusi. Terkait dengan hal tersebut, berikut hasil wawancara dengan subjek.

\section{Tahap Mengidentifikasi Masalah}

Peneliti : : "Oke, yang diketahui dari soal nomor 1 itu apa saja?”

Subjek Climber : "a-nya, awalnya, pada tahun 2011, 4 orang, terus pada tahun 2013 sebanyak 64 orang"

Peneliti : :Terus yang ditanyakan?"

Subjek Climber : “U5”

Hasil wawancara menyebutkan subjek dapat menyebutkan unsur yang diketahui dari permasalahan soal nomor 1 secara keseluruhan dan tepat, kemudian dapat menyebutkan dan menjelaskan pertanyaan yang diminta dengan benar. Berikutnya Subjek dapat menyebutkan unsur yang ditanyakan dalam butir soal nomor 1 kemudian menjelaskannya.

\section{Tahap Merumuskan Strategi}

Peneliti : : "Nah, solusi yang digunakan itu pakai rumus apa?”

Subjek Climber : "P akai rumus geometri, yang de, apa yang barisan, yang pakai $\operatorname{arni}\left(U_{n}=a \cdot r^{n-1}\right)$ "

Peneliti : "Nah selain pakai rumus $\operatorname{arni}\left(U_{n}=a \cdot r^{n-1}\right)$ ada rumus lain tidak sih menurut kamu?"

Subjek Climber : (Membaca soal) "Oh, pakai rumus yang pertumbuhan, yang itu, Mn sama dengan MO kali 1 tambah i pangkat $\mathrm{n}\left(M_{n}=M_{0}(1+i)^{n}\right)^{\prime \prime}$

Berdasarkan hasil wawancara, subjek dapat menentukan solusi yang dapat digunakan pada soal nomor 1 , sesuai dengan pengetahuan yang dimilikinya sekaligus menjelaskannya. Selain itu subjek juga mampu menyebutkan rumus lain yang sesuai dengan permasalahan tersebut, dimana rumus tersebut dapat menyelesaikan permasalahan nomor 1, meskipun tidak digunakan oleh subjek untuk menemukan hasil dari permasalahan tersebut pada tes tertulis.

\section{Tahap Melaksanakan Strategi}

Peneliti : : "Oke jelaskan!"

Subjek Climber : "a-nya kan tadi 4, r-nya kan, kan U3 sama dengan 64, U3 itu kan 4r pangkat 3 dikurangi $\left(4 . r^{3-1}\right)$ berarti $4 r$ pangkat 2 sama dengan $64\left(4 r^{2}=64\right), r$ kuadratnya sama dengan 16 $\left(r^{2}=16\right)$, r-nya sama dengan akar $16(r=\sqrt{16})$, $r$-nya sama dengan 4 , dicari $r$-nya melalui U3. U5 sama dengan pakai arni $\left(U_{n}=a . r^{n-1}\right)$, a, $\mathrm{r}$, n dikurang 1, U5-nya sama dengan $\mathrm{a}, \mathrm{r}$, 5 kurangi $1\left(U_{5}=a . r^{5-1}\right)$ U5-nya sama dengan 4 kali 4 pangkat $4\left(U_{5}=4.4^{4}\right)$, U5-nya sama dengan 4 pangkat $5\left(U_{5}=4^{5}\right)$, U5-nya 1.024 orang"

Hasil wawancara menyebutkan bahwa subjek dapat mengerjakan sesuai dengan rumus yang diutarakan pada pertanyaan sebelumnya. Kemudian menjelaskannya secara terperinci dengan informasi yang didapatkan sebelumnya untuk mendukung dalam melaksanakan strategi agar dapat menyelesaikan permasalahan pada butir soal nomor 1.

\section{Tahap Memverifikasi Solusi}

Peneliti : :Caranya gimana ini, ngeceknya?"

Subjek Climber : "Pakai rumus arni lagi $\left(a . r^{n-1}\right)$, U5-nya kan tadi 1.024, dimasukin. Terus a-nya nggak usah dimasukin dulu, terus 4 pangkat 5 kurangi $1\left(4^{5-1}\right), 1.024$ sama dengan a kali 4 pangkat 4 $\left(1.024=a .4^{4}\right), 1.024$ sama dengan a, 4 pangkat 4 kan 256, a-nya $4^{\prime \prime}$

Selain tahap mengidentifikasi masalah, tahap merumuskan masalah dan tahap melaksanakan strategi. Subjek juga mampu melalui tahap memverifikasi solusi. Hal ini dibuktikan pada jawaban wawancara, Subjek dapat menjelaskannya secara baik, bagaimana ia melaksanakan tahapan ini, yaitu dalam menjawab pertanyaan. Subjek dapat menjelaskan secara baik, bagaimana ia memeriksa kembali jawaban yang diminta. 


\section{Triangulasi}

Dilihat dari data di atas, telah diperoleh data tes tertulis dan analisis data wawancara, lalu dilakukan perbandingan untuk mengetahui valid tidaknya data yang diperoleh. Subjek mampu melalui tahap mengidentifikasi masalah, karena subjek dapat merumuskan unsur-unsur yang diketahui dan ditanyakan secara jelas dan tepat, serta dapat mengaitkan unsur yang diketahui dan ditanyakan, untuk melalui tahap selanjutnya dalam menyelesaikan permasalahan. Subjek mampu melalui tahap merumuskan masalah. Karena subjek dapat menentukan rumus yang dapat digunakan untuk menyelesaikan permasalahan, bahkan subjek mengetahui rumus selain yang digunakan untuk menyelesaikan permasalahan tersebut. Subjek mampu melalui tahap melaksanakan strategi. Karena subjek dapat melaksanakan seluruh rangkaian perhitungan dengan baik dan benar, sesuai dengan rumus yang telah ditentukan sebelumnya. Subjek juga mampu melalui tahap memverifikasi solusi. Karena subjek tidak hanya berhenti sampai menemukan hasil yang diinginkan, namun juga dapat mengecek kembali melalui hasil yang telah ditemukan.

Kemampuan Pemecahan Maslah Siswa Tipe Camper

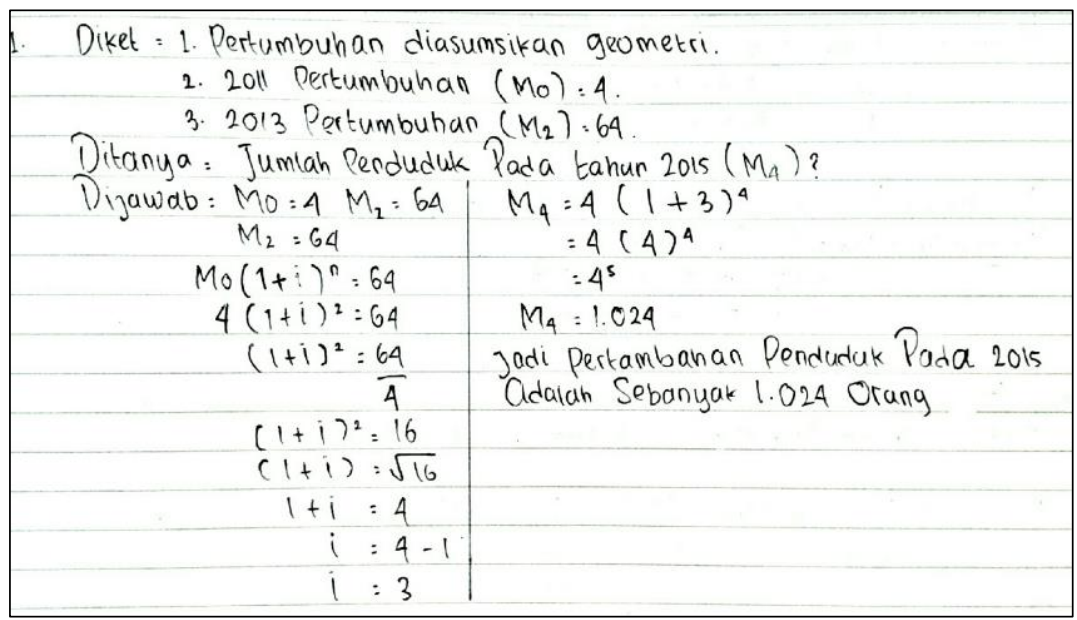

Gambar 3. Jawaban Subjek Informan Camper

Jawaban subjek pada Gambar 3 menunjukkan bahwa subjek mampu menulikan unsur yang diketahui dengan benar dan lengkap, yaitu subjek menyebutkan $M_{0}=4$ dan $M_{2}=64$, serta mampu menuliskan unsuryang ditanyakan yaitu $M_{4}$. Subjek juga mampu menggunakan menggunakan rumus $M_{n}=M_{0}(1+i)^{n}$. Akan tetapi subjek tidak mampu melaksanakan pemeriksaan kembali jawaban. Subjek hanya mampu sampai memberikan kesimpulan. Berdasarkan hasil tes tertulis, subjek mampu mengidentifikasi masalah, merumuskan masalah, melaksanakan strategi, akan tetapi tidak dapat melaksanakan pemverifikasian solusi. Terkait dengan hal tersebut, berikut hasil wawancara dengan subjek informan Camper:

Tahap Mengidentifikasi Masalah

Peneliti : :Oke, yang diketahui dari soal nomor 1 itu apa?"

Subjek Camper : "Pertumbuhan penduduk diasumsikan ikut barisan geometri, terus di 2011 itu ada pertumbuhan sebanyak 4 orang dan di 2013 itu ada sebanyak 64 orang. Kan 2011 pertama, jadi suku pertamanya itu aku jadiin $a$ sama dengan 4 , terus di 2013 itu suku ketiga $U_{3}$ sama dengan 64 begitu"

Penelit : :Ada lagi?"

Subjek Camper : "Yang ditanyakan jumlah penduduk pada tahun 2015, nah itu aku bikin $U_{5}$ "

Hasil wawancara menunjukkan bahwa subjek dapat menyebutkan unsur yang diketahui dari permasalahan soal nomor 1 secara keseluruhan dan tepat, serta dapat menyebutkan dan menjelaskan pertanyaan yang diminta dengan benar. Lalu Subjek dapat menyebutkan unsur yang ditanyakan.

Tahap Merumuskan Masalah

Peneliti : : "Nah pakai rumus apa?” 
Subjek Camper : "Kalau aku pakai rumus geometri, karena kalau pakai rumus yang satunya lupa.

Berdasarkan hasil wawancara, subjek dapat menentukan solusi yang dapat digunakan pada soal nomor 1 , sesuai dengan pengetahuan yang dimilikinya. Subjek juga mampu menyebutkan penyelesaian lain yang sesuai dengan permasalahan tersebut dimana penyelesaian tersebut dapat menyelesaikan permasalahan nomor 1, meskipun subjek lupa bentuk rumusnya.

\section{Tahap Melaksanakan Strategi}

Peneliti : "Oke coba jelaskan!”

Subjek Camper : "Jadi $a$-nya kan tadi 4, $U_{3}$-nya 64, dari situ kita cari rasionya dulu, rasionya ketemu 4, itu masukin ke rumus arninya $\left(a . r^{n-1}\right)$, jadi $U_{5}$ sama dengan 4 kali 4 , pangkat 5 kurangi $1\left(U_{5}=4.4^{5-1}\right)$, jadi 4 kali 4 pangkat 4 sama dengan $1.024\left(4.4^{4}=1.024\right)$.

Hasil wawancara menunjukkan subjek dapat mengerjakan sesuai dengan rumus yang diutarakan pada pertanyaan sebelumnya. Kemudian menjelaskannya secara terperinci.

Tahap Memverifikasi Solusi

Peneliti : "Sudah di cek kembali belum?"

Subjek Camper : "Udah. Diitung ulang begitu, ada yang salah nggak waktu ngaliin atau bagi begitu"

Subjek dapat melalui tahap mengidentifikasi masalah, tahap merumuskan masalah dan tahap melaksanakan strategi. Namun subjek tidak dapat melalui tahap memverifikasi solusi. Walaupun subjek dapat menjawab dan menjelaskannya, namun caranya tidak sesuai dengan indikator memverifikasi solusi pada pemecahan masalah.

\section{Triangulasi}

Dilihat dari data di atas, telah diperoleh data tes tertulis dan analisis data wawancara, berikutnya dilakukan perbandingan untuk mengetahui valid tidaknya data yang diperoleh. Subjek mampu melalui tahap mengidentifikasi masalah. Karena subjek dapat merumuskan unsur-unsur yang diketahui dan ditanyakan secara jelas dan tepat, serta dapat dapat mengaitkan unsur yang diketahui dan ditanyakan, untuk melalui tahap selanjutnya dalam menyelesaikan permasalahan. Subjek mampu melalui tahap merumuskan masalah. Karena subjek dapat menentukan rumus yang dapat digunakan untuk menyelesaikan permasalahan, bahkan subjek mengetahui rumus selain yang digunakan untuk menyelesaikan permasalahan tersebut. Subjek mampu melalui tahap melaksanakan strategi. Karena subjek dapat melaksanakan seluruh rangkaian perhitungan dengan baik dan benar, sesuai dengan rumus yang telah ditentukan sebelumnya. Subjek tidak mampu melalui tahap memverifikasi solusi. Karena subjek tidak menuliskan bagaimana cara memeriksa kembali, dan pada wawancara, cara mengecek tidak sesuai dengan indikator Kemampuan Pemecahan Masalah.

Kemampuan Pemecahan Maslah Siswa Tipe Quitter

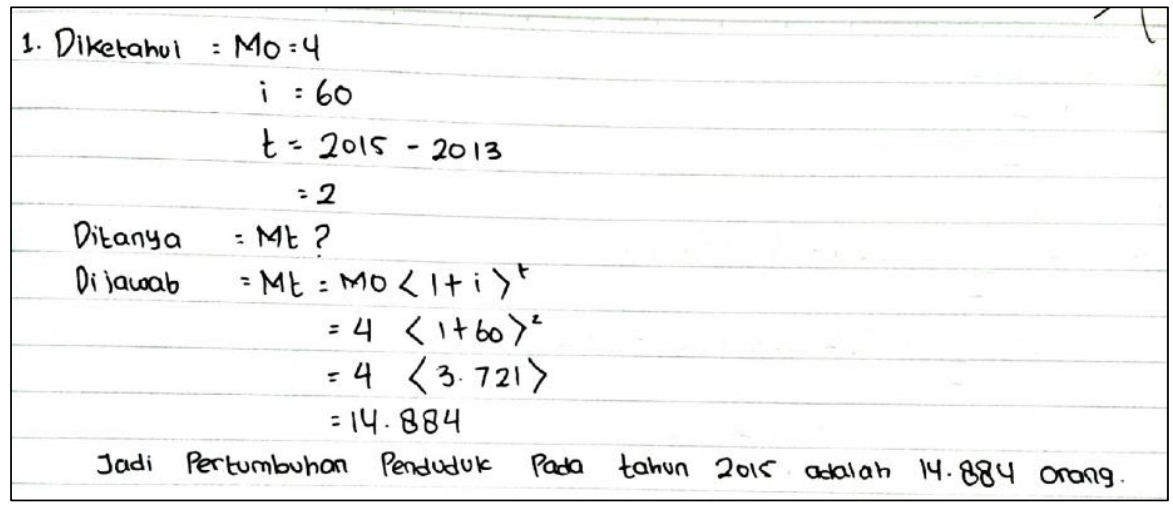

Gambar 4. Jawaban Subjek Informan Quitter

Gambar 4 menunjukkan bahwa subjek mampu menuliskan unsur yang diketahui yaitu $M_{0}=4, i=60$ dan $t=$ 2, meskipun beberapa unsur kurang tepat. Seharusnya subjek menuliskan $M_{2}=64$, dan mencari $i$ terlebih dahulu dengan rumus penyelesaian yang diketahui. Subjek juga mampu menuliskan unsur yang ditanyakan yaitu $M_{t}$, 
meskipun kurang spesifik. Subjek juga mampu menggunakan rumus $M_{t}=M_{0}(1+i)^{t}$. Akan tetapi subjek tidak mampu melaksanakan pemeriksaaan kembali jawaban. Subjek hanya mampu sampai memberikan kesimpulan. Berdasarkan hasil tes tertulis, subjek kurang mampu mengidentifikasi masalah, mampu merumuskan masalah, kurang mampu melaksanakan strategi, serta tidak mampu melaksanakan pemverifikasian solusi. Terkait dengan hal tersebut, berikut hasil wawancaranya:

\section{Tahap Mengidentifikasi Masalah}

Peneliti : :Dari soal itu yang diketahui apa saja?”

Subjek Quitter : "Pada tahun 2011 atau $M_{0} 4$ orang, $i$ atau bedanya 60 dan $t$ atau waktunya 2"

Peneliti : "Yang ditanyakan?"

Subjek Quitter : "Pertumbuhan penduduk pada tahun 2015 atau Mt-nya”

Hasil wawancara menunjukkan bahwa subjek dapat menyebutkan unsur yang diketahui dari permasalahan soal nomor 1, meskipun beberapa unsur kurang tepat. Lalu subjek dapat menyebutkan unsur yang ditanyakan, namun kurang spesifik.

\section{Tahap Merumuskan Masalah}

Peneliti : : "Terus waktu menyelesaikan masalah itu kamu menggunakan rumus atau solusi apa?" Subjek Quitter : " $M_{t}$ sama dengan $M_{0}$ kurung buka 1 plus $i$ kurung tutup pangkat $t\left(M_{t}=M_{0}(1+i)^{t}\right)$

Berdasarkan hasil wawancara, subjek dapat menentukan solusi yang dapat digunakan pada soal nomor 1 , sesuai dengan pengetahuan yang dimilikinya.

Tahap Melaksanakan Strategi

Peneliti : "Coba jelaskan!"

Subjek Quitter : "4kali 1 plus 60 pangkat dua $\left(4(1+60)^{2}\right), 4$ kali 61 pangkat $2\left(4(61)^{2}\right), 4$ kali 3.721 , hasilnya $14.884 "$

Hasil wawancara menunjukkan subjek dapat mengerjakan sesuai dengan rumus yang diutarakan pada pertanyaan sebelumnya. Akan tetapi karena terdapat bebrapa unsur yang kurang tepat, maka hasil penyelesaiannya juga kurang tepat.

Tahap Memverifikasi Solusi

Peneliti : "Sudah di cek?"

Subjek Quitter : "Belum"

Subjek tidak dapat melalui tahap memverifikasi solusi. Walaupun subjek menjawab pertanyaan.

Triangulasi

Dilihat dari apa yang telah dikemukakan sebelumnya, telah diperoleh data tes tertulis dan analisis data wawancara, kemudian dilakukan perbandingan untuk mengetahui valid tidaknya data yang diperoleh. Subjek kurang mampu melalui tahap mengidentifikasi masalah. Karena subjek dapat merumuskan beberapa unsur yang diketahui saja secara tepat, dan menyebutkan unsur yang ditanyakan, akan tetapi kurang spesifik. Subjek mampu melalui tahap merumuskan masalah. Karena subjek dapat menentukan rumus yang sesuai dengan permasalahan yang diberikan. Subjek kurang mampu melalui tahap melaksanakan strategi. Karena subjek tidak dapat melaksanakan seluruh rangkaian perhitungan dengan baik dan benar. Sehingga hasilnya tidak sesuai yang diinginkan. Subjek tidak mampu melalui tahap memverifikasi solusi. Karena subjek tidak mampu mengecek hasil.

\section{Pembahasan}

Berdasarkan hasil analisis data mengenai kemampuan pemecahan masalah siswa dalam menyelesaikan soal cerita pada materi barisan ditinjau dari $\mathrm{AQ}$, diperoleh informasi sebagai berikut.

\section{Kemampuan Pemecahan Masalah Tipe Climber}

Siswa bertipe Climber mampu memenuhi keempat indikator kemampuan pemecahan masalah yaitu mengidentifikasi masalah, merumuskan strategi, melaksanakan strategi, dan memverifikasi solusi. Hal ini senada dengan 
temuan penelitian Ningrum (2017, p.173), bahwa siswa yang bertipe Climber mampu menjelaskan hasil pekerjaannya yang telah ditulis dengan lancar dan benar pada sebuah permasalahan atau soal, serta menyebutkan fakta yang diketahui dengan baik dan benar.

Berdasaran hasil analisis data siswa bertipe Climber mampu menentukan rumus atau cara lain dalam menyelesaikan permasalahan atau soal. Hal ini sesuai dengan pendapat Lastri (Mardika \& Insani, 2017, p.24), bahwa Siswa bertipe Climber dapat memenuhi aspek proses berpikir kreatif dan mampu memahami masalah matematika dengan baik, sehingga siswa bertipe Climber cenderung dapat menemukan cara lain untuk memecahkan masalah.

Pada tahap memverifikasi solusi, siswa bertipe Climber mampu memeriksa ulang solusi yang ditemukan, sebagaimana indikator pada kemampuan pemecahan masalah. Adisti (Mardika \& Insani, 2017, p.25) juga mengungkapkan bahwa siswa bertipe Climber memecahkan masalah hingga tahap pemverifikasian solusi. Siswa bertipe Climber mampu melakukan pemeriksaan ulang dari hasil yang diperoleh dengan menafsirkan hasil ke informasi yang terkandung dalam masalah.

Temuan ini juga memperkuat pernyataan Stoltz (2000, p.29) bahwa Climber mempunyai komitmen untuk terus maju, melangkah ke depan dan mencapai tempat yang lebih tinggi. Begitu pun yang terjadi dengan siswa bertipe Climber, mereka berjuang dan berusaha mencari jawaban soal yang benar dan tepat, serta memiliki pemikiran lancar dan kreatif.

\section{Kemampuan Pemecahan Masalah Tipe Camper}

Siswa bertipe Camper mampu memenuhi 3 indikator kemampuan pemecahan masalah yaitu mengidentifikasi masalah, merumuskan strategi, dan melaksanakan strategi. Untuk indikator memverifikasi solusi, subjek bertipe Camper belum mampu melampauinya. Mereka hanya menghitung ulang seperti pengerjaan pada tahapan melaksanakan strategi.

Hasil analisis data peserta didik bertipe Camper menyebutkan bahwa mereka belum mampu menentukan rumus atau cara lain dalam menyelesaikan permasalahan atau soal. Hal ini sesuai dengan temuan Ningrum (2017, p.175), bahwa peserta didik yang bertipe Camper tidak mampu menyebutkan cara atau metode lain untuk menyelesaikan permasalahan, meskipun mereka mampu menjelaskan hasil pekerjaan yang ditulis dengan lancar dan benar.

Pada tahap memverifikasi solusi, peserta didik bertipe Camper belum mampu memeriksa ulang solusi yang ditemukan, sebagaimana indikator pada kemampuan pemecahan masalah. Subjek hanya menghitung ulang seperti pengerjaan pada indikator melaksanakan strategi. Adisti (Mardika \& Insani, 2017, p.24) juga mengungkapkan bahwa peserta didik bertipe Camper memecahkan masalah sampai tahap penyelesaian rencana. Dalam memahami masalah, peserta didik Camper menyatakan hal-hal yang diketahui dan ditanyakan menggunakan bahasa mereka sendiri. Lalu peserta didik Camper menyiapkan rencana penyelesaian dengan benar. Dalam mengeksekusi rencana pun, peserta didik menghitung dengan tepat. Namun peserta didik Camper belum dapat memeriksa kembali hasil yang diperoleh.

Stoltz (2000, p.25) mengungkapkan bahwa Camper memperlihatkan sedikit inisiatif dan sedikit semangat yang tinggi. Begitu pula yang terjadi pada peserta didik dengan AQ bertipe Camper dalam penelitian ini, mereka memiliki sedikit inisiatif dalam mengerjakan soal, dan memiliki pemikiran yang cukup lancar, serta masih berusaha untuk mengerjakan soal dengan mendapatkan jawaban yang terbaik.

\section{Kemampuan Pemecahan Masalah Siswa Tipe Quitter}

Siswa bertipe Quitter kurang mampu mengidentifikasi masalah, merumuskan strategi, melaksanakan strategi, dan tidak mampu memverifikasi solusi. Hasil analisis data peserta didik bertipe Quitter menunjukkan bahwa mereka belum mampu menyebutkan unsur yang diketahui dan ditanyakan secara tepat dan benar. Sehingga dalam proses pelaksanaan strategi, menghasilkan penyelesaian yang tidak tepat. Hal ini senada dengan temuan Ningrum (2017, p.177), bahwa peserta didik yang bertipe Quitter tidak mampu menyebutkan fakta yang diketahui pada soal dengan benar.

Hasil analisis juga menyebutkan bahwa peserta didik belum mampu dalam proses pelaksanaan strategi, mereka dapat menyebutkan strategi penyelesaiannya, namun tidak dapat mengeksekusi untuk mendapatkan hasil yang diminta. Lastri (Mardika \& Insani, 2017, p.24) juga mengungkapkan bahwa peserta didik yang bertipe Quitter, cenderung kurang mampu memahami masalah dengan baik dan hanya mampu memahami masalah terbatas 
pada apa yang dinyatakan. Sehingga berdampak pada ketidakmampuan peserta didik dalam memecahkan masalah.

Subjek bertipe Quitter tidak mampu memberikan cara atau solusi lain dalam menyelesaikan permasalahan. Lastri (Mardika \& Insani, 2017, p.24) menambahkan bahwa peserta didik yang bertipe Quitter, ketika diminta mencari cara atau jawaban lain, peserta didik cenderung tidak mampu mencari alternatif lain dan mudah menyerah. Stoltz (2000, p.31-32) juga mengungkapkan bahwa Quitter terampil dalam mengungkapkan kata-kata yang sifatnya membatasi seperti "tidak mau", "belum", "tidak bisa” dan lain-lain. Dalam wawancara subjek menjawab belum, ketika ditanya apakah sudah melaksanakan pengecekan ulang.

Pada tahap memverifikasi solusi, peserta didik bertipe Quitter belum mampu memeriksa ulang solusi sebagaimana indikator pada kemampuan pemecahan masalah. Adisti (Mardika \& Insani, 2017, p.24) mengungkapkan bahwa peserta didik bertipe Quitter tidak bisa mengembangkan rencana pemecahan masalah sehingga mereka gagal dalam tahap melaksanakan rencana dan memeriksa ulang soal.

\section{SIMPULAN}

Berdasarkan hasil penelitian dan pembahasan diperoleh beberapa kesimpulan. Pertama, peserta didik bertipe Climber mampu memenuhi keempat indikator pemecahan masalah yaitu memahami masalah, merumuskan strategi, melaksanakan strategi, dan memverifikasi solusi. Kedua, peserta didik bertipe Camper mampu memenuhi tiga dari empat indikator kemampuan pemecahan masalah yaitu memahami masalah, merumuskan strategi, dan melaksanakan strategi. Ketiga, peserta didik bertipe Quitter baru mampu memenuhi satu indikator kemampuan pemecahan masalah yaitu merumuskan strategi. Hal tersebut menunjukkan bahwa kemampuan pemecahan masalah siswa berbeda-beda jika ditinjau dari tipe $A Q$. Hal tersebut perlu menjadi perhatian bagi para pendidik dalam melaksanakan aktivitas pembelajaran matematika. Dalam hal ini pendidik perlu memberikan perhatian lebih terhadap peserta didik dengan tipe Quitter. Penggunaan masalah-masalah matematika yang menarik dan relevan dengan kehidupan sehari-hari diharapkan mampu memotivasi siswa untuk memecahkan masalah, terutama untuk meningkatkan ketertarikan dan daya juang siswa tipe Quitter. Selain itu, aktivitas-aktivitas pemecahan masalah perlu ditingkatkan dalam proses pembelajaran matematika, sehingga kemampuan pemecahan masalah peserta didik akan semakin terasah. Mengingat masih banyaknya keterbatasan dalam penelitian ini, diharapkan kepada peneliti lainnya untuk mengeksplorasi lebih lanjut terkait kemampuan pemecahan masalah siswa pada topik-topik lainnya, serta mengidentifikasi faktor-faktor lain yang ikut mempengaruhinya.

\section{DAFTAR PUSTAKA}

Amri, M. S., \& Abadi, A. M. (2013). Pengaruh PMR dengan TGT terhadap motivasi, sikap, dan kemampuan pemecahan masalah geometri kelas VII SMP. Pythagoras: Jurnal Pendidikan Matematika, 8(1), 55-68. doi: https://doi.org/10.21831/pg.v8i1.8494

Arfiana, A., \& Wijaya, A. (2018). Problem solving skill of students of senior high schools and Islamic high schools in Tegal Regency in solving the problem of PISA based on Polya's stage. Jurnal Riset Pendidikan Matematika, 5(2), 211-222. doi: https://doi.org/10.21831/jrpm.v5i2.15783

Bransford, J., \& Stein, B. S. (1993). The ideal problem solver: A guide for improving thinking, learning, and creativity. New York, NY: W. H. Freeman.

Depaepe, F., De Corte, E., \& Verschaffel, L. (2010). Teachers' approaches towards word problem solving: Elaborating or restricting the problem context. Teaching and Teacher Education, 26(2), 152-160. doi: https://doi.org/10.1016/j.tate.2009.03.016

Depdiknas. (2006). Peraturan Menteri Pendidikan Nasional Republik Indonesia Nomor 22 Tahun 2006 tentang Standar Isi Sekolah Dasar.

Espaňola, R. P. (2016). Adversity Quotient (AQ) and academic performance of selected students in MSU Marawi City. Proceedings Journal of Education, Psychology and Social Science Research Retrieved from https://ssrn.com/abstract=3136617

Greer, B. (1997). Modelling reality in mathematics classrooms: The case of word problems. Learning and Instruction, 7(4), 293-307. doi: https://doi.org/10.1016/S0959-4752(97)00006-6 
Hadi, S., Retnawati, H., Munadi, S., Apino, E., \& Wulandari, N. F. (2018). The difficulties of high school students in solving higher-order thinking skills problem. Problems of Education in the 21st Century, 76(4), 520-532. Retrieved from http://www.scientiasocialis.It/pec/node/files/pdf/vol76/520-532.Hadi_Vol.76-4_PEC.pdf

Kemendikbud. (2016). Peraturan Menteri Pendidikan dan Kebudayaan Republik Indonesia Nomor 21 Tahun 2016 tentang Standar Isi Pendidikan Dasar dan Menengah. Retrieved from https://bsnp-indonesia.org/wpcontent/uploads/2009/06/Permendikbud_Tahun2016_Nomor021.pdf/

Khairani, A. Z., \& Abdullah, S. M. S. (2018). Relationship between adversity quotient and academic well-being among malaysian undergraduates. Asian Journal of Scientific Research, 11(1), 51-55. doi: https://doi.org/10.3923/ajsr.2018.51.55

Kong, J. E., \& Orosco, M. J. (2016). Word-problem-solving strategy for minority students at risk for math difficulties. Learning Disability Quarterly, 39(3), 171-181. doi: https://doi.org/10.1177/0731948715607347

Mardika, F., \& Insani, S. U. (2017). Adversity quotientand student's problem solving skill in mathematics. Proceedings of 4th International Conference on Research, Implementation, and Education of Mathematics and Science (4th ICRIEMS). Retrieved from http://seminar.uny.ac.id/icriems/sites/seminar.uny.ac.id.icriems/ files/prosiding2017/ME04\%20Fitria\%20Mardika.pdf

Marlissa, I., \& Widjajanti, D. B. (2015). Pengaruh strategi REACT ditinjau dari gaya kognitif terhadap kemampuan pemecahan masalah, prestasi belajar dan apresiasi siswa terhadap matematika. Jurnal Riset Pendidikan Matematika, 2(2), 186 -196. doi: https://doi.org/10.21831/jrpm.v2i2.7333

Miles, M. B., \& Huberman, A. M. (1994). Qualitative data analysis (2nd ed.). London, UK: Sage Publications

Mustika, R., Yurniawati, Y., \& Hakim, L. E. (2018). Hubungan self confidence dan adversity quotient terhadap kemampuan pemecahan masalah matematik siswa. Jurnal Penelitian Pendidikan. 18(2): 228-230. Retrieved from https://ejournal.upi.edu/index.php/JER/article/viewFile/12964/7675

National Council of Teachers of Mathematics (NCTM). (2000). Principles and standards for school mathematics. Reston, VA: NCTM.

Ningrum, I. A. (2017). Analisis tingkat berpikir kreatif matematis peserta didik ditinjau dari adversity quotient kelas VIII MTs Muhammadiyah Bandar Lampung tahun ajaran 2016/2017 (Skripsi tidak diterbitkan). Universitas Islam Negeri Raden Intan, Lampung.

Parvathy, U., \& Praseeda, M. (2014). Relationship between adversity quotient and academic problems among student teachers. IOSR Journal of Humanities and Social Science, 19(1), 23-26. doi: https://doi.org/10.9790/0837191172326

Polya, G. (1957). How to solve it: A new aspect of mathematical method (2nd ed.). Pronceton, NJ: Princeton University Press.

Rianto, H., \& Santoso, R. H. (2014). Pengaruh pembelajaran inquiry dan problem solving terhadap motivasi dan prestasi belajar matematika. Pythagoras: Jurnal Pendidikan Matematika, 9(1), 1-10. doi: https://doi.org/10.21831/pg.v9i1.9055

Sajadi, M., Amiripour, P., Rostamy-Malkhalifeh, M. (2013). The examining mathematical word problems solving ability under efficient representation aspect. Mathematics Education Trends and Research, 2013, 1-11. Retrieved from http://www.ispacs.com/journals/metr/2013/metr-00007/

Stoltz, P. G. (2000). Adversity quotient: Mengubah hambatan menjadi peluang (Adversity Quotient: Turning Obstacles Into Opportunities). (T. Hermaya, Trans.). Jakarta: PT Grasindo. Original work published in 2000.

Sugiyono, S. (2016). Metode penelitian kuantitatif, kualitatif dan R\&D. Bandung: Alfabeta

Verschaffel, L., De Corte, E., \& Vierstraete, H. (1999). Upper elementary school pupils' difficulties in modeling and solving nonstandard additive word problems involving ordinal numbers. Journal for Research in Mathematics Education, 30(3), 265-285. doi: https://doi.org/10.2307/749836 
PYTHAGORAS: Jurnal Pendidikan Matematika, 14 (2), 2019 - 210 Linda Nur Chabibah, Emy Siswanah, Dyan Falasifa Tsani

Verschaffel, L., Greer, B., \& De Corte, E. (2000). Making sense of word problems. Educational Studies in Mathematics, 42(2), 211-213. doi: https://doi.org/10.1023/A:1004190927303 